\title{
EFEKTIVITAS SISTEM PENDISTRIBUSIAN RASKIN BERAS BERSUBSIDI UNTUK RUMAH TANGGA MISKIN
}

\author{
Drs. Almasri, M.Si
}

\begin{abstract}
Abstrak
Program Raskin pada dasarnya merupakan Program Operasi Pasar Khusus (OPK) yang diluncurkan pada Juli 1998 di bawah Program Jaring Pangan Sosial (JPS). Selama 14 tahun pelaksanaan program Raskin, berbagai pihak telah melakukan evaluasi dan hasilnya telah memberikan input bagi perbaikan konsep dan pelaksanaan program Raskin. Konsep tentang kemiskinan sangatlah beragam, mulai dari sekedar ketidakmampuan memenuhi kebutuhan konsumsi dasar dan memperbaiki keadaan, kurangnya kesempatan berusaha, hingga pengertian yang lebih luas yang memasukkan aspek sosial dan moral
\end{abstract}

Keyword : EffectivenessSystem, Distribution Raskin

\section{A Pendahuluan}

Kemiskinan merupakan masalah sosial yang senantiasa hadir di tengah-tengah masyarakat, khususnya di negara berkembang seperti Indonesia. Berbagai teori dan pengembangan pun terus menerus dikembangkan untuk mengatasi masalah ini. Gejala kemiskinan terus meningkat sejalan dengan krisis multidimensional yang masih dihadapi bangsa Indonesia. Krisis telah membawa Indonesia pada peningkatan angka kemiskinan terutama sebagai efek dari gejolak krisis moneter, untuk mengatasi masalah kemiskinan tersebut, maka pemerintah menggulirkan berbagai kebijakan salah satu antaranya adalah Program Raskin.

Program Raskin (Beras Untuk Rumah Tangga Miskin) merupakan program nasional yang bertujuan untuk membantu memenuhi kecukupan pangan dan mengurangi beban finansial rumah tangga miskin (RTM) melalui penyediaan beras bersubsidi. Sejak tahun 2007, Menteri Koordinator Kesejahteraan Rakyat (Menko Kesra) menjadi koordinator pelaksana Program Raskin untuk pendistribusian beras, Badan Urusan Logistik (BULOG) bertanggung jawab mendistribusikan dan pemerintah daerah bertanggung jawab menyalurkan beras dari titik distribusi kepada RTM .

Program Raskin pada dasarnya merupakan Program Operasi Pasar Khusus (OPK) yang diluncurkan pada Juli 1998 di bawah Program Jaring Pangan Sosial (JPS). Selama 14 tahun pelaksanaan program Raskin, berbagai pihak telah melakukan evaluasi dan hasilnya telah memberikan input bagi perbaikan konsep dan pelaksanaan program Raskin. Beberapa penyesuaian yang

\begin{tabular}{|c|c|c|c|}
\hline NO & TAHUN & $\begin{array}{c}\text { ALOKASI / } \\
\text { RTM }\end{array}$ & REALISASI \\
\hline 1. & 2006 & $45 \mathrm{~kg} / 3 \mathrm{~B} l \mathrm{n}$ & $20 \mathrm{~kg} / 3 \mathrm{~B} \ln$ \\
\hline 2. & 2007 & $30 \mathrm{~kg} / 3 \mathrm{Bln}$ & $20 \mathrm{~kg} / 3 \mathrm{~B} \ln$ \\
\hline 3. & 2008 & $45 \mathrm{~kg} / 3 \mathrm{Bln}$ & $25 \mathrm{~kg} / 3 \mathrm{~B} \ln$ \\
\hline 4. & 2009 & $45 \mathrm{~kg} / 3 \mathrm{Bln}$ & $20 \mathrm{~kg} / 3 \mathrm{Bln}$ \\
\hline 5. & 2010 & $45 \mathrm{~kg} / 3 \mathrm{~B} \ln$ & $20 \mathrm{~kg} / 3 \mathrm{Bln}$ \\
\hline 6. & 2011 & $45 \mathrm{~kg} / 3 \mathrm{~B} \ln$ & $25 \mathrm{~kg} / 3 \mathrm{Bln}$ \\
\hline
\end{tabular}

dilakukan antara lain meliputi perubahan nama, jumlah beras per rumah tangga, frekuensi distribusi, sumber dan jenis data, sasaran penerima manfaat dan penyediaan lembaga pendamping. 
Permasalahan kedua, frekuensi pendistribusian Raskin sejak juli 1998, pagu alokasi Raskin di distribusikan 12 kali dalam 1 tahun kecuali pada tahun 2006 hanya 10 kali dalam satu tahun. Tetapi yang terjadi di Kelurahan Sorek Satu tidak berjalan sesuai dengan apayang telah di tetapkan. Pendistribusian Raskin hanya di lakukan sebanyak 3-4 kali dalam 1 tahun, ini berarti pendistribusian hanya di lakukan 3-4 bulan sekali. Di tambah lagi dengan jadwal pendistribusian yang tidak dapat di tentukan sehingga RTM penerima manfaat Raskin tidak dapat memperkirakan kapan mereka akan mendapatkan Raskin.

Permasalahan ketiga, seharusnya Raskin disalurkan atau dijual kepada keluarga-keluarga miskin, ternyata banyak juga yang jatuh pada kelompok masyarakat lain yang bukan termasuk masyarakat yang memiliki kriteria untuk mendapat Raskin. Salah sasaran ini di karenakan oleh human error, dimana petugas lapangan atau oknumoknum di Kelurahan Sorek Satu malah membagi-bagikan Raskin pada keluarga dekat atau kerabat dekatnya.

Permasalahan ke empat, berhubungan dengan masalah sebelumnya yakni kesalahan jumlah keluarga miskin penerima Raskin .Hal ini di sebabakan akibat buruknya koordinasi antara Ketua RT (Rukun Tetangga) di Kelurahan Sorek Satu. Karena di Kelurahan Sorek Satu pembagian Raskin di lakukan langsung oleh Ketua RT yang bersangkutan . Akibatnya jumlah keluarga miskin yang terdata lebih sedikit dari yang sebenarnya. Dari hasil wawancara dengan Kasi Ketentraman dan Ketertiban sebagai pelaksana distribusi Raskin di Kelurahan Sorek Satu bahwa Pemerintah tingkat kelurahan memiliki wewenang untuk mengadakan Muskel (Musyawarah Kelurahan) di awal tahun yang di hadiri oleh Ketua RT untuk menentukan RTM yang berhak menerima Raskin, dalam Muskel ini sering kali terjadi kendala dalam menentukan
RTM karena mereka tidak begitu mengetahui indikator atau kriteria penerima manfaat Raskin . Hal ini lah yang menjadi masalah dalam penetapan jumlah penerima Raskin. Menurut lembaga penelitian SMERU hal ini merupakan kelemahan utama dalam program Raskin.

Permasalahan kelima,masalah pembayaran Raskin. Dari hasil wawancara dengan salah satu masyarakat kelurahan sorek satu yang mendapatkan Raskin, di ketahui bahwa masyarakat umumnya membayar tunai sebelum Raskin datang. Jika tidak membayar sebelum Raskin datang maka jatahnya akan ditawarkan pada orang lain yang bahkan tidak termasuk kriteria penerima Raskin. Ini di rasa sangat memberatkan, jika penerima Raskin memiliki uang saat pembayaran maka tidak menjadi masalah tetapi jika penerima Raskin tidak memiliki uang saat pembayaran maka mereka tidak dapat menikmati manfaat Raskin itu sendiri.

\section{B. Konsep Efektivitas \\ 1. Pengertian Efektivitas}

Konsep efektifitas sesungguhnya merupakan suatu konsep yang luas, mencakup berbagai faktor di dalam maupun di luar organisasi.Konsep efektifitas ini oleh para ahli belum ada keseragaman pandangan, dan hal tersebut dikarenakan sudut pandang yang dilakukan dengan pendekatan disiplin ilmu yang berbeda, sehingga melahirkan konsep yang berbeda pula di dalam pengukurannya. Namun demikian, banyak juga ahli dan peneliti yang telah mengungkapkan apa dan bagaimana mengukur efektifitas itu. Menurut Gunawan, adi dalam kamus besar bahasa indonesia (2003:113) menjelaskan bahwa efektifitas lebih bermakna pada hasil guna, yaitu hasil dari suatu kegiatan terhadap pelaksanaan kegiatan.Berdasarkan pengertian yang dikemukakan tersebut, efektifitas lebih menitik beratkan hasil dari pada kegiatan yang dilaksanakan .Jika kegiatan yang 
dilaksanakan berhasil maka kegitan tersebut dikatakan efektif. Pengertian yang sama juga di kemukakan oleh Kumorotomo,wahyudi (2005:365) efektifitas merupakan suatu pengukuran terhadap penyelesaian suatu pekerjaan tertentu dalam suatu organisasi dalam mencapai tujuannya, berhasil tidaknya suatu pekerjaan itu dilakukan .Di sini efektifitas di definisikan sebagia tolak ukur terhadap penyelesaian suatu pekerjaan, dapat dikatakan mencapai efektifitas apabila pekerjaan tersebut dapat mencapai tujuannya.

\section{Konsep Kemiskinan dan Indikator Kemiskinan}

Konsep tentang kemiskinan sangatlah beragam, mulai dari sekedar ketidakmampuan memenuhi kebutuhan konsumsi dasar dan memperbaiki keadaan, kurangnya kesempatan berusaha, hingga pengertian yang lebih luas yang memasukkan aspek sosial dan moral. Menurut Soekanto (2000:406) kemiskinan adalah sebagai suatu keadaan dimana seseorang tidak sanggup untuk memelihara dirinya sendiri yang sesuai dengan taraf hidup kelompoknya dan juga tidak mampu untuk memanfaatkan tenaga, mental maupun fisiknya dalam kelompok tersebut.

Masyarakat miskin adalah suatu kondisi dimana fisik masyarakat yang tidak memiliki akses ke prasarana dan sarana dasar lingkungan yang memadai, dengan kualitas perumahan dan pemukiman yang jauh di bawah standar kelayakan serta mata pencaharian yang tidak menentu yang mencakup seluruh multidimensi, yaitu dimensi politik, dimensi social, dimensi lingkungan, dimensi ekonomi dan dimensi asset (P2KP, Pedoman Umum, 2004:1).

Kemiskinan adalah ketidakmampuan individu dalam memenuhi kebutuhan dasar minimal untuk hidup layak (BPS dan Depsos, 2002:3). Kemiskinan dapat juga ditentukan dengan cara membandingkan tingkat pendapatan individu atau keluarga dengan pendapatan yang dibutuhkan untuk memperoleh kebutuhan dasar minimum. Dengan demikian, tingkat pendapatan minimum merupakan pembatas antara keadaan miskin dan tidak miskin. Konsep kemiskinan seperti ini dikenal sebagai konsep kemiskinan absolut. Pada kondisi lain bila tingkat pendapatan sudah mencapai tingkat pemenuhan kebutuhan dasar minimum, tetapi masih jauh lebih rendah bila dibandingkan dengan pendapatan masyarakat di sekitarnya. Dalam pengertian masih berada dalam keadaan miskin bila dibandingkan dengan keadaan masyarakat di sekitarnya. Konsep kemiskinan seperti ini dikenal sebagai kemiskinan relatif .

Dengan

demikian, sekurang-kurangnya ada dua pendekatan yang digunakan untuk pemahaman tentang kemiskinan, yaitu pendekatan absolut dan pendekatan relatif. Pendekatan pertama adalah perspektif yang melihat kemiskinan secara absolut yaitu berdasarkan garis absolut yang biasanya disebut dengan garis kemiskinan. Pendekatan yang kedua adalah pendekatan relatif, yaitu melihat kemiskinan itu berdasarkan lingkungan dan kondisi sosial masyarakat.

Indikator kemiskinan pada satu rumah tangga yang ditentukan Badan pusat Statistik adalah :

1. Luas lantai bangunan tempat tinggal kurang dari $8 \mathrm{~m} 2$ per orang;

2. Jenis lantai bangunan tempat tinggal terbuat dari tanah/bambu/kayu murahan;

3. Jenis dinding tempat tinggal terbuat dari bambu/rumbia/kayu berkualitas rendah/tembok tanpa plester;

4. Tidak memiliki fasilitas buang air besar atau bersama-sama dengan rumah tangga lain;

5. Sumber penerangan rumah tangga tidak menggunakan listrik;

6. Sumber air minum berasal dari sumur/mata iar tidak terlindungi/sungai/ air hujan; 
7. Bahan bakar untuk memasak sehari-hari adalah kayu bakar/arang/ minyak tanah;

8. Hanya mengkonsumsi daging/susu/ayam satu kali dalam seminggu;

9. Hanya membeli satu stel pakaian baru dalam setahun;

10. Hanya sanggup makan sebanyak satu/dua kali dalam sehari;

11. Tidak sanggup membayar biaya pengobatan di Puskesmas/Poliklinik;

12. Sumber penghasilan kepala rumah tangga adalah petani dengan luas lahan 0,5 ha, buruh tani, nelayan, buruh perkebunan atau pekerjaan lainnya dengan pendapatan di bawah Rp. 600.000,- (Enam ratus ribu rupiah)

13. Pendidikan teringgi kepala rumah tangga adalah tidak sekolah/tidak tamat $\mathrm{SD} /$ hanya SD;

14. Tidak memiliki tabungan/barang yang mudah dijual dengan nilai Rp. 500.000,(Lima ratus ribu rupiah) seperti sepeda motor (kredit/non kredit), emas, ternak, kapal motor atau barang modal lainnya.

Di tiap daerah memiliki ukuran tingkat kemiskinan tersendiri. Begitu juga di Kelurahan Sorek Satu, kelurga miskin di Kelurahan Sorek Satu akan berbeda dengan keluarga miskin di daerah lainnya. Dari hasil wawancara dengan Kasi Ketertiban dan Ketentraman Kelurahan Sorek Satu, Bapak Asril mengatakan adapun kriteria penerima Raskin di Kelurahan Sorek Satu adalah sebagai berikut :

1. Kepala kelurga tidak memilik penghasilan yang tetap tiap bulannya

2. Penghasilan yang didapat kepala keluarga antara Rp.800.000Rp.950.000/bulan

3. Di prioritaskan bagi janda yang telah renta dan tidak memiliki penghasilan yang cukup untuk memenuhi kebutuhan sehari-hari
4. Tidak memiliki rumah sendiri atau dinding rumah terbuat dari papan

5. Tidak memiliki tabungan maupun investasi yang bisa di andalkan untuk masa depan

\section{METODOLOGI}

Penelitian ini dilakukan di kelurahan Sorek Satu Kecamatan Pengkalan Kuras Kabupaten Pelalawan. Adapun jenis dan sumber data yang penulis gunakan dalam penelitian ini adalah :Data primeradalah data yang di peroleh melalui kegiatan yang dilakukan dilokasi penelitian (lapangan), melalui penyebaran quiestioner (membuat daftar pertanyaan), wawancara dan observasi. Dan data sekunder adalah data yang sudah diolah dan sudah ada sebelumnya yang di perlukan, seperti jumlah penduduk, pedoman umum Raskin baik dari Menteri Koordinator Kesejahteraan Rakyat maupun pedoman umum Raskin Kabupaten Pelalawan, kesepakatan bersama antara Bupati Pelalawan dan Perum Bulog dan jumlah penerima Raskin atau DPM.

Dan yang menjadi populasi dalam penelitian ini adalah seluruh rumah tangga miskin di Kelurahan Sorek Satu yang terdata di BPS yaitu sebanyak 203 KK. Kemudian untuk penelitian ini penulis mementukan sampel berdasarkan penentuan jumlah sampel yang di kembangkan Isaac dan Michael (Sugiono, 2003:98-99) mengambil 127 responden dengan tingkat kesalahan 5\%, hal ini berdasarkan tabel penentuan jumlah sampel dari populasi tertentu yang di kembangkan oleh Isaac dan Michael. Dengan pengambilan sampel melalui teknik sampling purposive yaitu dengan teknik penentuan sampel dengan pertimbangan-pertimbangan tertentu.

Dalam menganalisis data penelitian, peneliti akan mendeskripsikan atau menggambarkan secara utuh dan nyata mengenai efektifitas sistem pendistribusian Raskin di Kelurahan Sorek Satu, kemudian 
data di tuangkan kedalam bentuk tabel dengan angka untuk selanjutnya di analisis dengan deskriptif.

Adapun menurut Ari Kunto, dalam menganalisis penulis menuangkan dengan deskriptif kualitatif yaitu dengan menuangkan persentase dengan rumus sebagai berikut:

$$
\mathrm{P}=\frac{f}{n} \times 100 \%
$$

Dimana $: \mathrm{p}=$ Persentase $\mathrm{N}=$ Total Jumlah

$$
\mathrm{f}=\text { Frekuensi }
$$

\section{Hasil dan Pembahasan \\ 1. Efektifitas Sistem Pendistribusian Raskin (Beras Bersubsidi Untuk Rumah Tangga Miskin)}

Sistem pendistribusian Program Raskin telah mengalami beberapa kali penyesuaian, namun efektifitasnya masih diperdebatkan.Dari sisi penyaluran hingga titik distribusi, Badan Urusan Logistik (Bulog) telah melaksanakan tugasnya dengan relatif baik dan sesuai dengan pedoman program. Namun, penilaian keberhasilan program tidak dapat dilakukan secara parsial karena Program Raskin merupakan sebuah kesatuan program untuk menyampaikan beras bersubsidi kepada rumah tangga miskin (RTM).Permasalahan pelaksanaan Program Raskin banyak terjadi dari titik distribusi hingga rumah tangga penerima.

Menurut Pedoman Umum (Pedum) Raskin, keberhasilan Program Raskin diukur berdasarkan tingkat pencapaian indikator 6T, yaitu tepat sasaran, tepat jumlah, tepat harga, tepat waktu, tepat kualitas, dan tepat administrasi. Secara umum, hasil kajian terhadap pelaksanaan Program Raskin menunjukkan bahwa efektifitas sistem pendistribusian masih relatif lemah. Hal ini ditandai oleh sosialisasi dan transparansi yang kurang memadai; target penerima, harga, jumlah, dan frekuensi penerimaan beras yang kurang tepat; biaya pengelolaan program yang tinggi; pelaksanaan pemantauan yang belum optimal; dan mekanisme pengaduan yang kurang berfungsi.

Beberapa kendala dalam pelaksanaan Raskin selama ini terutama dalam pencapaian ketepatan indikator maupun ketersediaan anggaran. Sampai dengan saat ini, jumlah beras yang akan disalurkan baru ditetapkan setelah anggarannya tersedia. Selain itu ketetapan atas jumlah beras raskin yang disediakan juga tidak selalu dilakukan pada awal tahun, dan sering dilakukan perubahan di pertengahan tahun karena berbagai faktor. Hal ini akan menyulitkan dalam perencanaan penyiapan stoknya, perencanaan pendanaan dan perhitungan biaya-biayanya.

Untuk mencapai tepat sasaran, tepat harga dan tepat waktu, beberapa penyempurnaan terus dilakukan.Salah satunya adalah dengan pola distribusi yang berkembang tidak hanya melalui titik distribusi yang langsung disalurkan kepada RTS namun juga melalui Warung Desa (Wardes). Melalui Wardes, penyaluran Raskin menjadi lebih dekat kepada RTS dan RTS membeli beras secara bertahap sesuai daya belinya selama 1 bulan dengan harga sesuai dengan ketetapan. Penyaluran melalui Wardes berawal dari pilot project pada akhir tahun 2008 dan mulai diimplementasikan sejak tahun 2009.

Dalam pelaksanaan penyaluran beras Raskin, perlu penegasan kembali bahwa Raskin bukan hanya program Perum Bulog tetapi menyangkut semua pihak. Perlu kerjasama dengan Pemda dan jajarannya.Untuk lebih jelasnya dibawah ini akan di sajikan alur pendistribusian Raskin.

Alur pendistribusian Raskin di Kelurahan Sorek Satu di awali dengan pihak Kelurahan menyetor uang Raskin pada pihak Kecamatan sejumlah beras yang akan di terima pihak Kelurahan, dan untuk Kelurahan Sorek Satu memilik 203 RTM yang tersebar di 29 RT. Setelah uang ditransferkan dari 
pihak Kecamatan kepada pihak Bulog maka pihak Kecamatan akan menginformasikan kepada Satgas Raskin yang bertugas di Kabupaten Pelalawan untuk mendistribusikan Raskin di Kelurahan Sorek Satu. Kemudian Satgas Raskin tersebut akan menyiapkan beras untuk di distribusikan keKecamatan Pangkalan Kuras. Setelah sampai di Kecamatan beras langsung di bongkar dan di tempatkan di Rumah Dinas Kecamatan, hal ini di lakukan karena Kecamatan Pangkalan Kuras tidak memiliki gudang tersendiri. Langkah selanjutnya pihak Kecamatan akan mendistribusikan pada desa/kelurahan yang ada, setelah beras sampai di Kelurahan Sorek Satu maka pelaksana distribusi Raskin Kelurahan Sorek Satu akan mengirim informasi kepada semua ketua RT yang ada di Kelurahan Sorek Satu. Kemudian ketua RT akan membawa beras Raskin ke rumahnya ( titik bagi) sesuai dengan jumlah RTM yang ada di wilayahnya. Setelah beras Raskin tersebut sampai maka ketua RT akan langsung membagikan pada RTM yang ada. Tiap RTM kan di bebani dengan biaya transportasi, upah timbang dan pembelian kantong plastik. Begitulah sistem pendistribusian Raskin yang ada di Kelurahan Sorek Satu.

Selanjutnya untuk mengetahui efektifitas sistem pendistribusian Raskin ( beras bersubsidi untuk rumah tangga miskin) di Kelurahan Sorek Satu Kecamatan Pangkalan Kuras Kabupaten Pelalawan di tetapkan beberapa indikator yang relevan, yang pembahasannya dapat di jelaskan sebagai berikut :

\section{1.a Tepat Waktu}

Menurut pedoman umum Raskin yang di terbitkan oleh Mentri Koordinator Kesejahteraan Rakyat, Raskin di distribusikan sebanyak 12 kali dalam setahun. Itu berarti raskin di distribusikan 1 kali dalam sebulan, namun temuan di lapangan Raskin di distribusikan sebanyak 3 bulan sekali dengan jadwal pendistribusian yang tidak dapat di tentukan. Hal ini menjadikan RTM penerima Raskin tidak dapat memastikan kapan mereka mendapatkan Raskin.

Dari temuan penelitian dilapangan tentang ketepatan waktu pendistrubusian Raskin terlihat jelas bahwa pendistribusian Raskin di Kelurahan Sorek Satu belum memiliki ketepatan waktu.Para RTM memang sangat membutuhkan beras Raskin untuk memenuhi kebutuhan sehari-harinya, maka dari itu mereka lebih setuju jika Raskin di distribusikan sebanyak sebulan sekali.

Setelah di lakukannya penelitian di Perum Bulog, Kecamatan Pangkalan Kuras, Kelurahan Sorek Satu , RTM-PM. Di temukan bahwa sebenarnya masalah ini sangat terkait dengan sistem pembayaran yang ada.

Dari hasil wawancara dengan Ketua Satker Raskin Provinsi Riau yang mendistribusikan Raskin ke Kabupaten Pelalawan, mengatakan bahwa pihak Bulog akan mendistribusikan Raskin setelah pihak Kecamatan menginformasikan untuk segera mendistribusikan Raskin ke Kecamatan. Pihan Bulog juga menetapkan sistem pembayaran di muka, yang artinya pihak Kecamatan harus menyiapkan uang untuk kemudian mentransfernya ke rekening Perum Bulog sesuai dengan jumlah beras Raskin yang di di distribusikan ke Kecamatan Pangkalan Kuras.

Sedangkan pihak Kecamatan sendiri terkadang memiliki keterlambatan dalam mengumpulkan uang dari tiap Kelurahan atau Desa Sekecamatan Pangkalan Kuras, mengingat pangkalan kuras sendiri memiliki 12 desa/ kelurahan.Dan pihak Desa/kelurahan pun harus mengumulkan uang dari setiap RT di Desa/Kelurahanya. Untuk kelurahan Sorek Satu sendiri memiliki 29 RT. Dan menurut pengakuan dari beberapa RT yang saya wawancarai, mereka mengaku cukup kesulitan untuk menyetor uang beras Raskin 
tersebut pada pihak Kelurahan Sorek Satu. Karena mereka harus menutupi tagihan beras Raskin sesuai dengan berapa RTM-PM Yang ada di wilayah RT yang ia pimpin. Dalam penyelesaian pembayaran beras dapat di bayangkan berapa lama waktu yang di butuhkan untuk bisa menyetorkan uang pada pihak Bulog. Dalam pedoman umum program Raskin Kabupaten Pelalawan Tahun 2012 pada bab 4 tentang mekanisme pelaksanaan pada point 4.5 pembayaran harga penjualan beras di nyatakan bahwa pelaksana distribusi Raskin tidak di benarkan menunda pembayaran harga pembelian beras raskin kepada satker Raskin atau rekening HPB Bulog di bank. Namun hal ini ternyata tidak berlaku di kecamatan pangkalan kuras karena ketidak sanggupan RTM dalam memenuhi pembayaran beras Raskin yang di dapatkannya.

Pihak Perum Bulog mengaku sengaja memberlakukan sistem seperti itu karena banyak kasus di Kabupaten lain yang sampai sekarang masih memiliki tunggakan dalam pembayaran Raskin. Jadi Perum Bolog memberlakukan cara ini untuk mengantisipasi kerugian yang lebih besar lagi.

Dari hasil penelitian penulis dilapangan Ketidak tepatan dalam pendistribusian Raskin juga di sebabkan kerena kecamatan tidak memiliki gudang untuk menampung Raskin yang di distribusikan oleh Perum Bulog.Selama ini beras yang ada hanya di tampung di rumah Dinas Kecamatan, jadi pihak Kecamatan cukup kerepotan dalam menampung Raskin yang ada. Apalagi jarak antara Perum Bulog dengan Kecamatan Pangkalan Kuras cukup jauh, jika perum Bulog pagi hari berangkat untuk mendistribusikan Raskin maka sore harinya baru tiba di kecamatan Pangkalan Kuras, setibanya di Pangkalan Kuras pihak kecamatan tidak bisa langsung mendistribusikan Raskin ke desa-desa / kelurahan kerena terkendala dengan waktu, susahnya mencari pekerja untuk membongkar muatan serta kesiapain dari aparat desa/ kelurahan itu sendiri. Jadi beras tersebut untuk sementara di letekkan diperumahan dinas kecamatan yang kapasitasnya juga tidak memadai untuk menyimpan Beras Raskin yang ada.

Pelaksana distribusi Raskin dikecamatan menyatakan bahwa biaya operasional dari pemerintah kabupaten yang di berikan kepada kecamatan untuk mendistribusikan Raskin ke seluruh desa/ kelurahan yang ada di kecamatan Pangkalan Kuras di keluarkan 3 bulan sekali. Maka pendistribusian Raskin tidak dapat di distribusian tiap bulannya.Inilah yang menjadi salah satu penyebab ketidak tepatan waktu dalam pendistribusian Raskin. Sehingga RTM tidak dapat memastikan kapan bisa mendapatkan Raskin untuk bisa memenuhi kebutuhan mereka sehari-hari. RTM hanya bisa menunggu informasi dari ketua RT yang ada di wilayahnya kapan Raskin datang untuk selanjutnya di distribusikan pada RTM.

\section{1.b Tepat Sasaran}

Di Kelurahan sorek satu memiliki 203 RTM-PM pada tahun 2011 yang tercantum dalam DPM. 203 RTM-PM ini tersebar dalam 9 RW dan 29 RT yang ada di kelurahan sorek satu. 203 RTM-PM ini merupakan hasil pendataan dari BPS Kebupaten Pelalawanberdasarkan data PPLS08.

Data RTS yang dinamis menjadi suatu kendala tersendiri di lapangan. Masih ada RTM di lain yang belum dapat menerima Raskin karena tidak tercatat sebagai RTM di BPS. Kebijakan lokal dan "keikhlasan" sesama RTM dalam berbagi, tidak jarang dipersalahkan sebagai ketidak tepatan sasaran.

Para ketua RT yang ada di Kelurahan Sorek Satu mengambil kebijakan untuk membagi rata beras Raskin pada tiap $\mathrm{KK}$ yang ingin membelinya, hal ini di lakukan 
untuk menghindari kecemburuan sosial antar masyarakat dan menghindari keributan yang bisa saja terjadi. Menurut wawancara penulis dengan ketua RT 03 RW 04 Kampung Baru Bapak Heri di kediamannya pada tanggal 15 November 2012 mengatakan bahwa, " kebijakan seperti ini memang harus di ambil agar tidak ada keributan yang di timbulkan akibat pendistribusian yang tidak merata, terkadang ada KK yang tidak terdaftar di kelurahan sebagian penerima Raskin tapi mereka tetap ngotot untuk mendapatkan Raskin".Hal yang sama juga di utarakan oleh ketua RT 03 RW 09 Engkolan Bapak Afini Efri, baliau juga mengatakan terpaksa melakukan hal ini untuk menghindari hal-hal yang tidak di inginkan terjadi di wilayahnya.

Kuantitas Raskin yang didapat per RT sebenarnya telah sesuai dengan jumlah RTM ditiap RT, namun beras Raskin yang diterima tiap RT ini harus di bagikan tidak hanya untuk RTM yang terdaftar di DPM Kecamatan maupun Kelurahan tapi juga pada KK yang tidak terdaftar. Ini karena beberapa KK yang ada di kelurahan Sorek Satu merasa layak untuk mendapatkan beras Raskin, padahal secara financial mereka jauh lebih mampu di bandingkan dengan RTM yang terdaftar di DPM. Inilah yang menjadi penyebab RTM harus rela berbagi dengan yang lain karena paradigma di masyarakat itu sendiri ternyata sangat buruk. Mereka merasa pantas mendapatkan berasRaskin, padahal ada orang yang jauh lebih membutuhkannya.

Sedangkan musyawarah kelurahan yang di adakan tiap setahun sekali oleh pihak Kelurahan yang menghadirkan seluruh RT, RW dan tokoh-tokoh masyarakat yang ada di kelurahan sorek satu ternyata belum mampu menanggulangi masalah pendataan RTM yang ada, menurut penuturan para RT sendiri mereka tidak mengetahui dengan jelas bagaimana menentukan tingkat kemiskinan dari masyarakat yang ada di wilayahnya. Selama ini mereka hanya menilai dari sisi perekonomian dan kedekatan personal yang tidak mendasar sehingga terkadang ada KK yang lebih miskin tetapi mereka tidak mendapatkan Raskin. Ini merupakan hasil dari observasi penulis yang di lakukan di lapangan.

BPS sendiri telah memilik indikator untuk mendata kemiskinan tersebut.Indikator kemiskinan di ukur dengan ukuran makro dan ukuran mikro. Ukuran makro adalah pengeluaranperkapita dan pendapatan. Sedangkan ukuran mikro meliputi:Pekerjaan, Penghasilan, Bangunan rumah, Sumber air, Bahan bakar memasak, Aset yang dimiliki, Pangan, Pakaian, Lantai rumah, Dinding rumah, Atap rumah Dan sumber penerangan. Jadi sebenarnya BPS telah melakukan tugasnya dengan cukup baik akan tetapi angka kemiskinan ini terus meningkat seiring berjalannya waktu. Di kelurahan sorek satu sendiri banyak pendatang dari luar kota maupun luar provinsi yang hingga kini banyak yang belum terdata sehingga tak heran jika ternyata di lapangan masih banyak keluarga miskin yang tidak terdata oleh BPS. Kerena BPS sendiri melakukan kerja sama dengan pihak kecamatan dan kelurahan untuk melakukan pendataan tiap tahunnya. Pegawai BPS kabupaten pelalawan sendiri mengakui bahwa kendala pendataan keluarga miskin di lapangan ternyata banyak yang tidak jujur, langkah-langkah pendataan yang di lakukan BPS adalah ( Hasil wawancara dengan anggota BPS kabupaten Pelalawan):

a. Pegawai BPS berkordinasi dengan aparat desa/kelurahan untuk mengumpulkan KK miskin menurut penilaian dari aparatur Desa/Kelurahan

b. Dari tiap KK tersebut di kumpulkan di suatu tempat untuk kemudian di wawancarai oleh pegawai BPS berdasarkan indikator-indikator yang telah di sebutkan di atas.

c. Dari hasil wawancara tersebut maka pegawai BPS akan menilai dan menentukan KK yang termasuk dalam indikator kemiskinan tersebut 
d. Kemudian pegawai BPS akan memberi angket untuk tiap KK yang termasuk dalam indikator kemiskinan

e. BPS akan mengolah data yang di dapat dari lapangan.

Data yang di keluarkan BPS belum mencakup warga miskin di daerah tersebut.Masih banyak warga yang seharusnya layak menerima raskin tidak terdata.Hal ini berdampak pada jumlah yang seharusnya diterima oleh masyarakat menjadi berkurang karena harus berbagi dengan mereka yang tidak terdata.Maka muncullah fenomena "warga miskin ikhlas berbagi".Jika kita melihatnya secara hukum positif maka jelas hal ini melanggar aturan sebab tidak sesuai dengan peraturan perundangan yang telah ditetapkan.Akan tetapi jika dilihat dari kacamata sosiologis maka hal tersebut 'terpaksa' harus dilakukan demi untuk meredam gejolak sosial.Fenomena ini ternyata berdampak juga pada ketidaktepatan harga.

Dalam pendistribusian Raskin ketidak tepatan dalam menentukan sasaran penerima manfaat juga di karenakan terlalu banyaknya pihak-pihak yang di libatkan dalam mengimplementasikan program Raskin. Pada ahir tahun 2011 di bentuk TNP2K ( Tim Nasional Percepatan Penanggulangan Kemiskinan). Dan pada tahun 2012 pemerintah membuat kebijakan baru dalam sistem pendataan rumah tangga sasaran penerima manfaat Raskin dengan mengacu pada data yang yang di berikan oleh TNP2K yaitu sistem basis data terpadu program perlindungan sosial yang mencapai $40 \%$ dari jumlah penduduk. Setiap program dalam klaster perlindungan sosial harus menetapkan kriteria kepersertaan dan mengajukan ke TNP2K untuk di proses dan di tentukan jumlah pesertanya atau rumah tangga sasaran penerima raskin. Sistem ini di harapkan semua RTM dan dapat menjadi RTS dan tidak menimbulkan kesenjangan data.
Namun fakta di lapangan berkata lain,dari hasil wawancara dengan pelaksana distribusi di tingkat Kabupaten,Bapak Erwan selaku Kasubbag produksi pada Bagian Ekonomi Sekretariat Daerah Kebupaten Pelalawan menyatakan bahwa " ada perbedaan yang sangat jauh sekali antara data TNP2K dengan data dari BPS, dari data yang ada TNP2K ternyata cenderung menekan angka kemiskinan yang ada sekitar 50\%. Ini lah yang kadang membuat kami sebagai petugas Raskin Kabupaten bingung.Perbedaan data ini bisa jadi akan menimbilkan gejolak di masyarakat".

\section{1.c Lingkungan Sosial, Ekonomi dan Politik}

Dalam pendistribusian Raskin ini kebijakan yang sering diambil baik oleh pihak pemerintah kabupaten, kelurahan maupun aparat kelurahan sangat mempengaruhi tingkat efektifitas sistem pendistribusian Raskin yang ada. Untuk pemerintah kabupaten sendiri telah membuat kebijakan berupa Pedoman umum Program Raskin Kabupaten Pelalawan, ini merupakan peraturan yang di buat oleh bupati untuk menjabarkan pelaksanaan program Raskin di Kabupaten yang harus di sesuaikan dengan Pedoman Umum Raskin yang di terbitkan oleh Menteri Koordinator Kesejahteraan Rakyat. Di dalam Pedoman umum Program Raskin ini menjadi pedoman di Kabupaten untuk melaksanakan Raskin. Pemerintah juga telah melakukan MOU dengan pihak Perum Bulog untuk menentukan titik distribusi Raskin. Penentuan titik distribusi yang telah di lakukan di rasa kurang tepat karena titik distribusi tersebut terlalu jauh dari jangkauan RTM. Sehingga RTM masih banyak di bebankan biaya operasional, ini berakibat dengan harga beras Raskin yang melonjak. Sedangkan lingkungan intern yang dikenal sebagai iklim organisasi yaitu lingkungan yang secara keseluruhan dalam lingkungan organisasi.Hal ini berkaitan dengan strukrur 
organisasi yang ada, yang menggambarkan keadaan di dalam oganisasi untuk iklim organisasi yang ada di perum Bulog,pemerintah kabupaten, kecamatan dan kelurahan sorek satu sudah cukup bagus dari hasil penelitian penulis hanya kerja sama tim yang kurang di kembangkan sehingga sering terjadi penumpukan tugas karena ada beberapa pegawai yang bersikap acuh.

\section{1.d Sikap Para Pelaksana}

Karektristik pekerja yang terlibat dalam pendistribusian Raskin ini sangat menentukan tingkat efektifitas dari sistem pendistribusian Raskin itu sendiri.Menurut penelitian dari penulis sendiri ternyata orangorang yang berkaitan dengan pendistribusian Raskin belum mampu bekerja secara profesional dan optimal. Karena tidak adanya semangat kerja dan keterikatan dengan pekerjaannya,sehingga kinerja dari tiap pegawai masih kurang efektif.

Keberhasilan implementasi kebijakan sangat tergantung dari kemampuan memanfaatkan sumber daya yang tersedia. Dan manusia merupakan sumber daya yang terpenting dalam menentukan keberhasilan suatu implementasi kebijakan. Setiap tahap implementasi menuntut adanya sumber daya yang berkualitas sesuai dengan pekerjaan yang di isyaratkan oleh kebijakan yang telah di tetapkan secara politik.

Menurut pendapat Van Mater dan Van Horn bahwa sikap penerimaan atau penolakan dari agen pelaksana kebijakan sangat mempengaruhi keberhasilan atau kegagalan implementasi kebijakan publik. Hal ini sangat mungkin terjadi karena kebijakan yang di laksanakan bukanlah hasil formulasi warga setempat yang mengenal betul permasalahan dan persoalan yang mereka rasakan. Tetapi kebijakan publik biasanya bersifat top down yang sangat mungkin para pengambil keputusan tidak mengetahui bahwa tak mampu menyentuh kebutuhan, atau permasalahan yang harus di selesaikan.

Kebijakan program Raskin yang di laksanakan memang bersifat top down, Sehingga pemerintah tidak mengerti apa sebenarnya apa yang menjadi permasalahan dan kebutuhan masyarakat. Seperti masalah pendataan masyarakat penerima Raskin. Di lapangan ternyata masih banyak rumah tangga miskin yang tidak terdata, menjadikan timbulnya cemburu sosial dalam masyarakat yang dapat berakibat terhadap timbulnya konflik laten.

Sikap mereka itu di pengaruhi oleh pandangan terhadap suatu kebijakan dan cara melihat pengaruh kebijakan itu terhadap kepentingan-kepentingan organisasinya dan kepentingan pribadinya. Van Mater dan Van Horn menjelaskan disposisi bahwa implementasi kebijakan diawali penyaringan lebih dahulu mengenai persepsi dari pelaksana dalam batas mana kebijakan itu di laksanakan.

Terdapat tiga macam elemen respon yang dapat mempengaruhi kemampuan dan kemauan untuk melaksanakan suatu kebijakan, antara lain terdiri dari pertama, pengetahuan, pemahaman dan pendalaman terhadap kebijakan. Kedua, arah respon mereka apakah menerima, netral atau menolak dan ketiga, intensitas terhadap kebijakan.

Sebaliknya, penerimaan yang menyebar dan mendalam terhadap standar dan tujuan kebijakan diantara mereka yang bertanggung jawab untuk melaksanakan kebijakan tersebut, adalah merupakan suatu potensi yang besar terhadap keberhasilan implementasi kebijakan. Pada ahirnya, intensitas disposisi para pelaksana dapat mempengaruhi pelaksana kebijakan. Kurangnya atau terbatasnya intensitas disposisi ini akan bisa menyebabkan gagalnya implementasi kebijakan. 


\section{KESIMPULAN DAN SARAN 1.1 Kesimpulan}

Dari penelitian yang telah di lakukan, ternyata memang banyak sekali di temukan kendala- kendala dalam sistem pendistribusian Raskin di Kelurahan Sorek Satu.Kendala tersebut terjadi akibat kebijakan pemerintah yang kurang tepat, sumber daya manusia yang menjalankan kurang berkompeten dan belum bisa menjaga profesionalitas kerja, pengaruh lingkungan yang tidak kondusif mengakibatkan paradigma berpikir yang sempit serta struktur organisasi yang sangat kompleks. Hal - hal tersebut menjadikan program Raskin yang di laksanakan di kelurahan Sorek Satu belum bisa di katakan efektif dan masih perlu pembenahan agar program mulia dari pemerintah pusat ini tidak mubajir dan menjadi ladang kesempatan bagi oknumoknum yang ingin mendapatkan keuntungan di balik implementasi program Raskin ini. Hal ini terbukti dengan hasil penelitian yang di lakukan penulis terhadap 6 indikator dari efektifitas program Raskin. Pendistribusian Raskin di kelurahan sorek satu tidak memiliki ketepatan waktu karena terkendala masalah pembayaran. Sistem pembayaran Raskin yang di tetapkan oleh pihak Bulog mengharuskan pelaksana pendistribusian Raskin kecamatan dan kelurahan harus menyiapkan uang untuk di transferkan ke rekening Bulog sebelum Raskin tersebut di distribusikan ke kelurahan sorek satu. Sedangkan RTM terlambat untuk menyetorkan uang Raskin tersebut. Sehingga ini menambah lamanya waktu pendistribusian Raskin. Sedikitnya rumah tangga miskin yang terdaftar di DPM menyebabkan ketua RT di kelurahan sorek satu harus membagi Rata beras Raskin yang di dapat untuk rumah tangga yang ada di wilayahnya. Hal ini di lakukan untuk menekan konflik atau kecemburuan sosial yang bisa terjadi. Padahal dalam pedoman umum Raskin yang di terbitkan oleh bupati pelalawan tahun
2012 telah di jelaskan bahwa tidak di benarkan membagikan Raskin pada RTM yang tidak terdaftar di DPM-1. Akibat dari kebijakan yang di ambil oleh ketua RT di kelurahan Sorek Satu, maka ada pengurangan jumlah jatah beras Raskin yang saharusnya di terima RTM, karena hak merekadi kurangi untuk di bagi pada RTM yang lainnya. Dari pantauan penulis di lapangan RTM yang terdaftar di DPM hanya mendapat beras hanya mendapat $10 \mathrm{~kg} / 3$ bulannya seharusnya mereka menerima $45 \mathrm{~kg} / 3$ bulannya. Dari hasil wawancara dan observasi yang di lakukan penulis, ternyata pelaksana distribusi Raskin di kelurahan belum mampu melaksanakan proses administrasi dengan baik, laporan-laporan maupun berkas berkas seperti DPM, berita acara musyawarah kelurahan belum di selesaikan. Ini terlihat ketika penulis menanyakan tentang hal itu tapi ternyata berkas dan laporan tersebut belum di siapkan. Ketepatan harga Raskin di kelurahan sorek satu terkendala dengan biaya transfortasi, upah timbang dan penyedian kantong plastik. Tidak adanya penetapan harga yang baku menyebabkan harga yang bervarasi di tiap RT yang ada di kelurahan sorek satu, harga yang ada berkisar antara Rp.2.100-2.300/ kg di titik bagi. Dari hasil penelitian penulis ternyata banyak RTM yang mengeluhkan tentang kualitas beras Raskin, jika di tinjau dari umur para RTM yang berkisar antara 65 tahun ke atas mencapai $28,57 \%$ dari 203 RTM yang ada. Mereka mengeluhkan kualitas beras yang teksturnya terlalu keras sehingga sulit untuk di konsumsi. Untuk mengatasi itu mereka terpaksa harus mencampurnya dengan kualitas beras yang lebih bagus agar bisa di konsumsi. Hal ini tentu menambah pengeluaran RTM bukan malah mengurangi.

\section{DAFTAR PUSTAKA}
A.M. Sardiman 2011. "Interaksi dan Motivasi Belajar-Mengajar", Rajawali Pers, Jakarta.


Behrendt Richard F, 1974, "Siasat Kemasyarakatan" bagi negaranegara yang sedang berkembang, Pradnya Paramita, Jakarta.

Bertrand, Alvin, L, 1980 "Sosiologi” Bina Ilmu Surabaya.

Burns, Tom. R, Thomas Bumgartner, Philippe Devilie, 1987 "Manusia, Keputusan, Masyarakat”. Pradya Paramita, Jakarta.

Chester L. Hunt B. Harton, 1996 "Sosiologi Jilid 2". Erlangga.

Cohen J. Bruce, 1992. "Sosiologi dan Perubahan Sosial", Bina Aksara, Jakarta.

Damsar, 2009. "Pengantar Sosiologi Ekonomi". Kencana Prenada Media Group. Jakarta.

Gunawan, Ary H., 2000. "Sosiologi Pendidikan (Suatu Analisis Sosiologi Tentang Pelbagai Problem Pendidikan". PT. Rineka Cipta, Jakarta.

Hasibuan, Melayu, SP. 2000. Manajemen Sumber Daya Manusia. Bumi Aksara. Jakarta.

Jalil, Ashaluddin, 2010. Mengapa Datang ke Pulau Batam : Daya Tarik Industri Sampai Masalah Migrasi" Universitas Riau Press, Pekanbaru.

Johnson, Paul Doyle, 1986a. "Teori Sosiologi Klasik dan Modern Jilid I" terjemahan Lawang M.Z. Robert, PT. Gramedia. Jakarta.
Putra, Heddy Sri Abimsa (Penyunting), 2003. "Ekonomi Moral, Rasional dan Politik Dalam Masyarakat Industri Kecil di Jawa”, Kepel Press. Yogyakarta.

Ritzer, George, 2004. "Sosiologi Ilmu Pengetahuan Berparadigma Ganda", PT. Raja Grafindo Persada. Jakarta.

Ritzer, George dan Douglas J. Goodman, 2004. "Teori Sosiologi Modern", diterjemahkan Alimandan, Preda Media. Jakarta.

Sajogyo dan Pudjiwati Sajogyo, 1990 "Sosiologi Pedesaan" Jilid I Gadja Mada University Pers. Yogyakarta.

Scott, James C, 1981. "Moral Ekonomi Petani : Pergerakan dan Subsistensi di Asia Tenggara Terjemahan Hasan Basri suntingan Bur Rasuanto. LP3ES, Jakarta.

Siagian, Sondang P, 2004. "Teori Motivasi dan Aplikasinya”. PT. Rineka Cipta. Jakarta.

Sudijono, Anas ,2003. "Pengantar Statistik Deskriptif". CV. Sumber Ilmu, Jakarta.

Svalastoga, Kaare, 1989. "Difrensiasi Sosial", terjemahan Alimandan, SU. Bina Aksara.

Syahza, Almasdi, 2002. "Potensi Pembangunan Industri Hilir Kelapa Sawit di Daerah Riau", dalam Usahawan Indonesia, No. 04/TH XXXI April 2002. Lembaga Manajemen FE UI, Jakarta. 